\title{
Territorial justice and equity criteria - spatial planning in Ticino
}

\author{
Mosè Cometta \\ Department of Philosophy and Education Sciences, University of Turin, Turin, Italy \\ Correspondence: Mosè Cometta (mose.cometta@unito.it)
}

Received: 16 March 2021 - Revised: 25 October 2021 - Accepted: 4 November 2021 - Published: 1 December 2021

\begin{abstract}
This paper analyses from a philosophical and interdisciplinary point of view two master plans of the canton Ticino - the first one from 1990, Keynesian, and the second one from 2009, neoliberal. The differences between the former and the latter are highlighted on a conceptual level. While the former stresses the importance of rebalancing and maintaining internal solidarity between the regions of the canton, the latter aims to make the canton more competitive and specialised. The discussion highlights how this type of analysis, by showing the political and moral concepts and criteria underlying a master plan, favours their political discussion and thus, ultimately, the implementation of a more inclusive planning process.
\end{abstract}

\section{Introduction}

This paper provides a theoretical and philosophical reading of spatial planning. There are multiple reasons for doing so. Philosophy and the social sciences, at least since the contribution of the Frankfurt School (Horkheimer and Adorno, 2002), Gramsci (1971) and Foucault (2006), have grasped the importance of analysing the conceptual and ideological discourses that underlie seemingly everyday and banal acts and institutions. This has contributed to the generation of an interesting line of study that sees master plans and spatial planning as an influential political-narrative tool (Richardson and Jensen, 2003; Ambal, 2019; Callon, 2006; Ostrowetsky, 1993 ) and thus as a privileged place from which to analyse certain phenomena such as the rise of neoliberalism (Allmendinger and Haughton, 2013; Haughton et al., 2013; Olesen, 2012; Ranci, 2017; Olesen, 2013; Morel Journel and Pinson, 2017).

Spatial planning is a subject that lies at the very heart of a society that makes the active management of space one of the cornerstones of its economic structure (Harvey, 2011). This centrality implies that choices about spatial planning will necessarily be political choices; i.e. they will affect the sociopolitical development of society (e.g. Gaeta, 2011). Spatial planning is therefore inextricably linked to politics on the one hand and, as a legitimising frame, to the quest for justice and equity (Soja, 2010; Lefebvre, 2001, 1991) - since the choices made will have to be justified in relation to a certain ideal model of society that is to be achieved. Every spatial planning choice thus implies a set of political values - a certain way of interpreting justice - which can be highlighted in order to understand the vision of society underlying institutional action.

Contemporary society is predominantly urban (Lefebvre, 1970). This means that we have moved from the duality of ways of life in traditional societies - which distinguished rural territories from cities quite clearly - to a society in which the urban is everywhere (Lefebvre, 2001), albeit in distinct degrees (Lévy, 1994). Contemporary territories, in the West but increasingly globally, are marked by ways of life that are only marginally different. The same technologies articulate the rhythms in valleys and urban centres alike - the centrality of the internal combustion engine, the internet and mobile telephony being key examples. The phenomenon is so farreaching that there are authors who argue for the hypothesis of planetary urbanisation, claiming that even the orbits of the sky in which satellites fly and the seas on which container ships sail are now spaces that actively shape urban society (Arboleda, 2015; Brenner, 2018; Schmid and Brenner, 2011; Shaw, 2015; Kanai, 2014).

This transition from rural to urban is not a simple transformation of built space but implies major changes in lifestyles and societies. This paper focuses on the management of this 


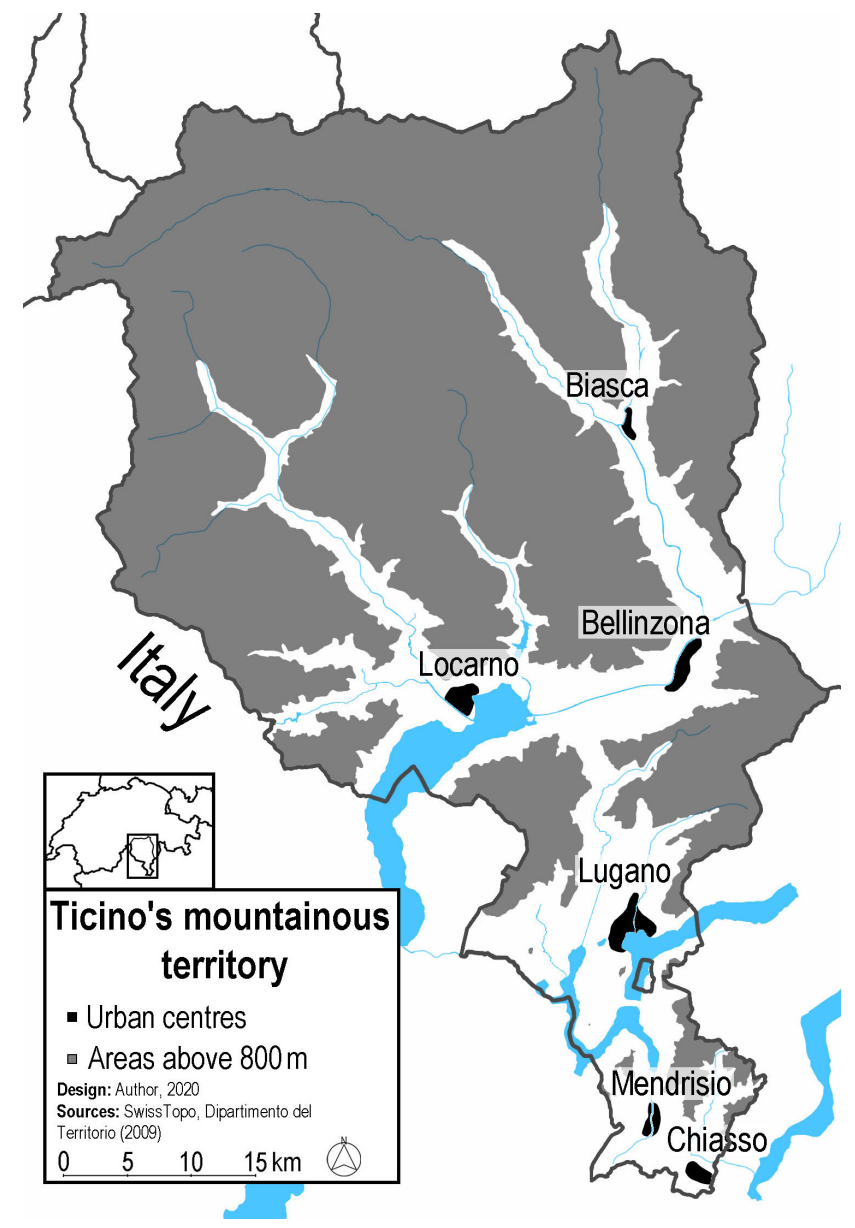

Figure 1. Ticino's physical geography.

transition by the canton of Ticino, a Swiss region, which has published two different master plans over the last 40 years. Our intention is to analyse the reasoning behind these plans. We do not intend to take a position between the two perspectives that will be presented but simply show the rationale for their existence and their limitations. This is a fundamental task, since a careful critique can contribute to better decisionmaking.

\section{Case study}

Ticino is the only Swiss canton to be located entirely south of the Alps and is the southernmost region of Switzerland. It has a territory that degrades from the Alps to the Po Valley, characterised by both very impervious areas and a few flatter areas (Fig. 1). Historically, it has a past of military colonisation by both Milan and the Swiss German cantons. Indeed, it is a strategic area for controlling transit traffic on the northsouth axis: the northern valleys of the canton provide access to the Nufenen, St Gotthard and Lukmanier passes, as well as the San Bernardino pass in Graubünden.
The morphological complexity of the territory and the different colonial regimes have led to a fairly significant local differentiation. This can be seen, for example, in the diversity of dialects spoken and in the traditional primary activities: pastoralism, farming or subsistence agriculture (Ceschi, 1998). This has led to a series of political tensions, especially concerning the relationship between the northern, Alpine part and the southern part, which is closer to Italian culture (Ghiringhelli, 1998).

Thus the canton arose on a very unstable basis: imposed and unwanted, having to manage a very diverse and divided territory, and facing a strongly parochial sentiment spread throughout the population (see Todd, 2015). This led to a fundamentally weak central power structure in a society with fundamentally pre-industrial characteristics (Rossi et al., 1979). It was only after the Second World War that the first major drives towards economic and social centralisation and the promotion of cantonal power in economic life appeared, and they mainly failed (Ceschi and Ghiringhelli, 1998; Toppi, 1998a, b).

With the advent of urban society in the mid-twentieth century, the canton saw a dramatic increase in the number of buildings within a regulatory vacuum (Carloni, 1998): from the 1940s to the 1970s the number of buildings doubled (Caccia, 1984). The power of territorial planning was in the hands of the municipalities, which were totally unprepared for handling this new situation and implemented oversized and inconsistent master plans (Carloni, 2011). Economic and demographic dynamics of tertiarisation and centralisation also contributed to further emptying the peripheral valleys. It was a complete upheaval of Ticino society. "After the Second World War, the favourable international situation and the opening of the Italian border, followed 35 years later by the Gotthard road tunnel and the uninterrupted motorway link with the major cities of northern Europe and the Lombardy metropolis, and then, in the last decade, the choice of hightech companies to set up in the peripheral regions favoured by their climate and the quality of their living environment, are all factors that have enabled Ticino to make full use of its geographical location. The canton's geographical position is changing from marginal to central, giving it a role as an intermediary and mediator between the major economic regions on either side of the Alps"1 (Limouzin, 1990:173).

Swiss spatial planning is a complex domain, in which different actors and scales negotiate land use guidelines. The Federal Act on Spatial Planning of 22 June 1979, art 2, states that the confederation, cantons and municipalities must coordinate and plan activities that have a spatial impact. This law laid the foundations for spatial planning in Switzerland and obliged Ticino to adopt a master plan (PD90) - approved in 1990. This master plan has no direct effect on the land but sets out the criteria to be adopted by local authorities drawing up operational planning (Maggiori et al., 2003). The federal

\footnotetext{
${ }^{1}$ Any non-English texts quoted have been translated.
} 
ordinance on spatial planning of 28 June 2000 , art 5, specifies that the master plan must describe the spatial development objectives; the planning achievements of the canton; and its cooperation with other cantons, the Confederation and neighbouring countries. The cantonal law on territorial development of 21 June 2011, art 9 and 10, indicates that the master plan consists of three elements: the planning objectives, the sheets and the plans. While the objectives express the general direction of the canton and its priorities, the sheets and plans specify the objectives and indicate how and when they will be implemented. A revision of PD90 has been implemented in 2009: the 2009 Master Plan (PD09). This revision is part of a larger shift in the cantonal institutions' conception of the canton. "Since the beginning of the 2000s, participating in a movement that has involved a significant part of the Swiss cantons, Ticino has experienced a profound redefinition of its internal institutional borders" (Mazzoleni, 2013:9). PD09 and the policy of municipal aggregations launched at the beginning of the millennium show a political understanding of Ticino that is increasingly at odds with that expressed in PD90. The aim of this paper is to explore this shift of perspective.

\section{Methodology}

The texts of the two cantonal master plans were analysed, as well as numerous accompanying texts that are part of their dossiers. The analysis, which is interdisciplinary in nature, is based on critical analysis (Foucault, 2015; Hajer, 2003) and content analysis (Mucchielli, 1996). This made it possible to focus on the motivations and arguments that structure and legitimise the plans. As shown by Kohlbacher (2006) and Wodak and Reisigl (2016), a methodology combining qualitative analysis and critical discursive analysis allows the combination of both theory-guided and problem-oriented perspectives. The philosophical and theoretical perspective with which the texts were approached, following the idea that planning is a political-narrative tool (Richardson and Jensen, 2003; Ambal, 2019; Callon, 2006; Ostrowetsky, 1993), fits perfectly with the aims of this paper. The methodological limitations of this paper are technical and empirical: this research focuses neither on specific measures nor on economic effects of planning policies but only on what they say about society.

\section{Results}

\subsection{The PD90 territorial policy}

As we have already argued, Ticino is a structurally and historically weak canton, whose central power is hampered as much by history and culture as by territorial constraints (such as mountains and morphological differences between the north and south). Ticinese society, which still had preindustrial characteristics in the first half of the twentieth cen- tury, has rapidly become urban. Rural society, in which subsistence farming was prevalent and the territory was managed through widespread micro-ownership, had no need for institutional planning instruments. Each local community was self-regulating; the living conditions themselves prevented a reduction in agricultural land (Rossi et al., 1979). With the advent of urban society, on the other hand, the workforce became increasingly concentrated in the service sector. The need for built-up space increased exponentially, corresponding with the enrichment of the population and the abandonment of subsistence farming. This upheaval took place in less than 20 years, too quickly for a change in cultural perception to materialise. When the canton was obliged to draw up a master plan in 1980, the institutional balance of power underwent a radical transformation: a competence which had always been local now became an emanation of the canton. "[T]he PD is the culmination of a long conversion, a true Copernican revolution, whereby we have moved from predominant (though not exclusive) municipal competence to pre-eminent cantonal competence and responsibility, with a reversal of the point of observation from which to look at spatial planning" (Lepori, 1981:51). However, this was not a complete turnaround: municipalities were not excluded from planning activities at either a local or a cantonal level. On the contrary, in the 1980s, "unlike in the 1970s (especially the debate on the Urban Planning Law), the focus has shifted from the concept of 'municipal autonomy' to that of 'participation' by municipalities in cantonal planning. The explanation for this different perspective is manifold: the urban planning reality of recent decades, the increasingly pronounced consultancy and implementation interventions on the part of the canton on the municipal fabric, and also the impotence felt by many municipal administrators to contain the phenomenon of unrestrained edification have transformed the contrasting positions and interests into an increasing request for help and protection from the municipalities and therefore for collaboration between the cantonal and local authorities" (Lepori, 1981:53). Thus, PD90 was not conceived as the topdown imposition of a coherent territorial vision by the canton but rather as the canton assuming the role of coordinating local visions (Rossi, 1986:44). Thus, this master plan is the result of a negotiation between the canton and the municipalities imposed by the confederation in which the canton still has a very weak political role as well as a certain lack of expertise. Moreover, cantonal planning came basically too late to deal with the exponential increase in the number of new buildings and was therefore unable to have any real impact on the urban fabric that was being established. In this regard, and in an attempt to speed up approval of the master plan, the canton has deliberately presented a generic, non-detailed vision (Antonini, 1983:85).

In terms of the territorial conception, it is interesting to note that PD90 makes a veiled criticism of the excesses and imbalances of municipal planning without, however, questioning the legitimacy of the municipality as the backbone 
of social and political life. E.g. it remarks that "the process of regionalisation, or at least of supra-municipal organisation to find coordinated solutions to the many problems above the local level, is incomplete" (RCT, 1990:II.7). The Master Plan recognises that the new urban society is changing people's living spaces - the economic and functional spaces no longer correspond to the municipality territories (RCT, 1990:II.8). Nevertheless, the structure of the municipalities and their territoriality are not called into question by the canton.

On the contrary, PD90 is striving to redress the socioeconomic and demographic imbalances generated by urban society in a fundamentally Keynesian way. One of its fundamental objectives is in fact to avoid further peripheralisation and marginalisation of the Alpine valleys, which would increase inequalities (RCT, 1990:II.153). According to PD90, cantonal solidarity should thus be increased so that wealthy urban municipalities contribute to financing infrastructure in weaker and more remote ones (RCT, 1990:II.14). This translates into identifying sub-poles to be developed through public investment (Fig. 2) and into the will to avoid the centralisation of economic services and infrastructures in urban hubs and, on the contrary, to spread them throughout the canton in contrast to economic logic (RCT, 1990:II.15). In other words, despite a veiled criticism of the poor territorial management of municipalities, PD90 is still strongly imbued with a political idea of territorial balance. This means that the various regions of the canton should not be excessively marked by economic and demographic differences. The canton therefore plans to ensure a sufficient demographic and economic distribution to guarantee the survival of mountain municipalities (RCT, 1990:II.86) and even reverse the declining trends in peripheral areas (RCT, 1990:II.88).

\subsection{The PD09 territorial policy}

PD09 is a departure from PD90 for several reasons. First of all, the canton intends to avoid the delays that characterised the first master plan, and to do so it wants to rely more on collaboration with various players (public and private) in setting planning objectives. These, in turn, will be less ambitious and more achievable (Del Priore and Celio, 2006). This is not just a local change but responds to a broader change in thinking at all scales. According to a new spatial planning approach at the Swiss level, urban areas should be strengthened and favoured as they "are the driving forces behind Switzerland's economic activity" (CF, 2001:11). This is an important change as it shows that political attitudes have changed. "During its first period of implementation (19741996), regional policy was oriented towards peripheral and mountain regions and essentially pursued a redistributive objective. Since 1996, however, the main thrust of the new regional policy has been to promote the competitiveness and sustainable development of the regions, taking into account their specific needs and potential" (CF, 2001:15). Even Ticino promotes this trend, pointing out the differences be-

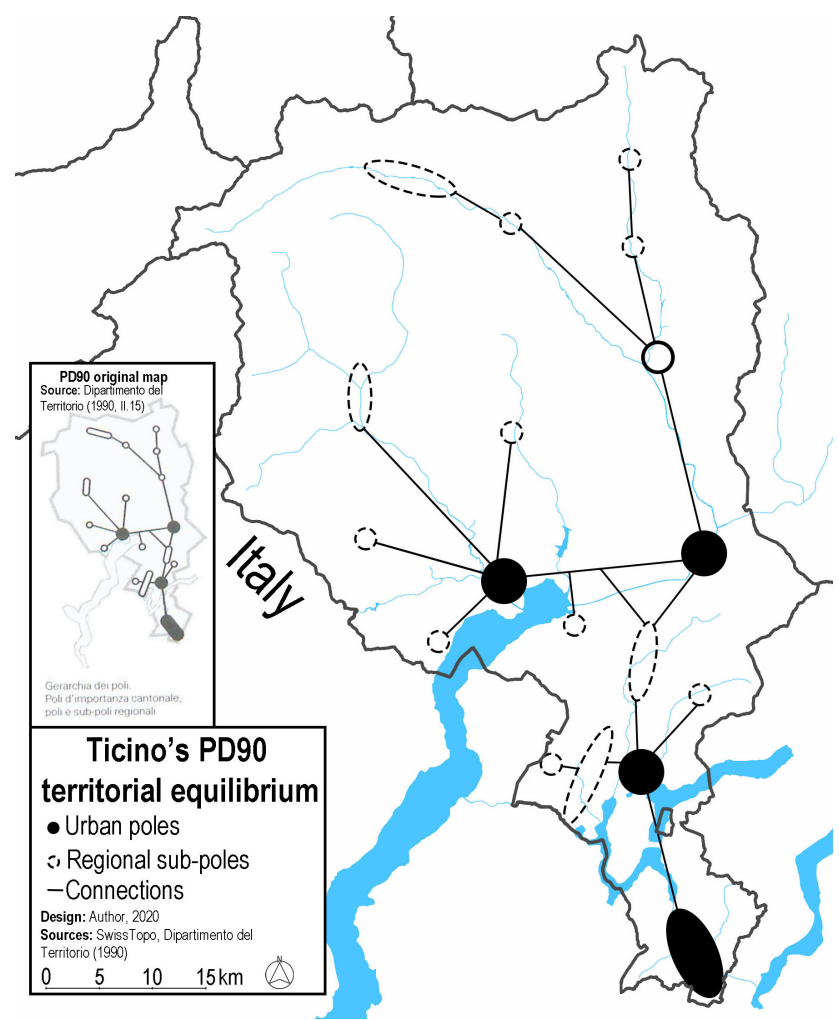

Figure 2. Ticino's 1990 master plan objectives.

tween the socio-territorial situation in the 1980s and that of the 2000s (RCT, 2003:5). Specifically, emphasis is placed on the dynamics of globalisation which render the management of local-scale phenomena increasingly difficult. Progressive interconnection imposes greater competition on urban fabric, which must therefore organise itself more efficiently in order to remain attractive. For this, "promotional measures should therefore be geared more towards the challenges facing the regions and regional potential and no longer towards interregional disparities" (RCT, 2003:19). The focus on internal regional inequalities - which have continued to increase in the 2000s (OST, 2008, 2010, 2016) - is abandoned so as not to divert energy from the fight for global competitiveness (Table 1).

This change in perspective is fully applied in Ticino's territorial policies of the 2000s. The canton, like others in Switzerland (Mazzoleni, 2013:9), introduced a policy of gradual municipal aggregation. Municipalities, which had been the result of territorial subdivisions of rural society, were in fact inadequate to deal with complex urban problems. Furthermore, many municipalities were too small to be able to carry out their activities without depending on cantonal assistance; this effectively reduced municipal autonomy, a major feature of the federalist system (RCT, 1998b:3). In 2000, there were still 101 municipalities with fewer than 400 inhabitants in Ticino, 79 with between 400 and 1200 inhabitants, and with just 65 above 1200 inhabitants (USTAT, 2018) - 
Table 1. Some of the objectives of the master plans. PD90 had 110 targets, while PD09 has 29. Here we summarise only those most relevant to the socio-territorial balance of the canton.

\begin{tabular}{|c|c|c|c|}
\hline PD90 objectives & Author's comment & PD09 objectives & Author's comment \\
\hline $\begin{array}{l}\text { Promoting the hierarchy of cen- } \\
\text { tralities, implementing the ser- } \\
\text { vices and infrastructures essen- } \\
\text { tial to the role assigned to urban } \\
\text { poles and regional sub-poles } \\
\text { (RCT, 1990:III.5) }\end{array}$ & $\begin{array}{l}\text { Objective A.0.a.1 aims to de- } \\
\text { velop the territory of the canton } \\
\text { as a whole. }\end{array}$ & $\begin{array}{l}\text { Promoting Ticino's competi- } \\
\text { tiveness by supporting its poly- } \\
\text { centricity: three areas and four } \\
\text { urban agglomerations (RCT, } \\
2007: 16 \text { ) }\end{array}$ & $\begin{array}{l}\text { Objective } 9 \text { focuses on the ur- } \\
\text { ban elements of the canton. } \\
\text { Support for the development } \\
\text { of peripheral areas disappears } \\
\text { from the discourse. }\end{array}$ \\
\hline $\begin{array}{l}\text { To promote, within Ticino, } \\
\text { the coordination and integration } \\
\text { of urban agglomerations and } \\
\text { their complementarity (RCT, } \\
\text { 1990:III.5) }\end{array}$ & $\begin{array}{l}\text { Objectives A.0.c and A.0.c. } 1 \\
\text { aim to avoid an imbalance in } \\
\text { favour of Lugano. }\end{array}$ & $\begin{array}{l}\text { Support the development of } \\
\text { policies coordinated by neigh- } \\
\text { bouring cantons for Alpine ar- } \\
\text { eas (RCT, 2007:17) }\end{array}$ & $\begin{array}{l}\text { Objective } 10 \text { marks the clear } \\
\text { separation of two areas within } \\
\text { the canton: the urban area (dealt } \\
\text { with in Objective 9) and the } \\
\text { mountain area. These will have } \\
\text { separate development aims. }\end{array}$ \\
\hline $\begin{array}{l}\text { Promoting socio-economic de- } \\
\text { velopment specific to each dis- } \\
\text { trict and increasing cantonal } \\
\text { solidarity (RCT, 1990:III.5) }\end{array}$ & $\begin{array}{l}\text { Objective A.0.d aims to support } \\
\text { peripheral regions. }\end{array}$ & & $\begin{array}{l}\text { It is significant that in the en- } \\
\text { tire document describing the } 29 \\
\text { objectives of PD09, there is not } \\
\text { once a mention of the concept } \\
\text { of solidarity. }\end{array}$ \\
\hline
\end{tabular}

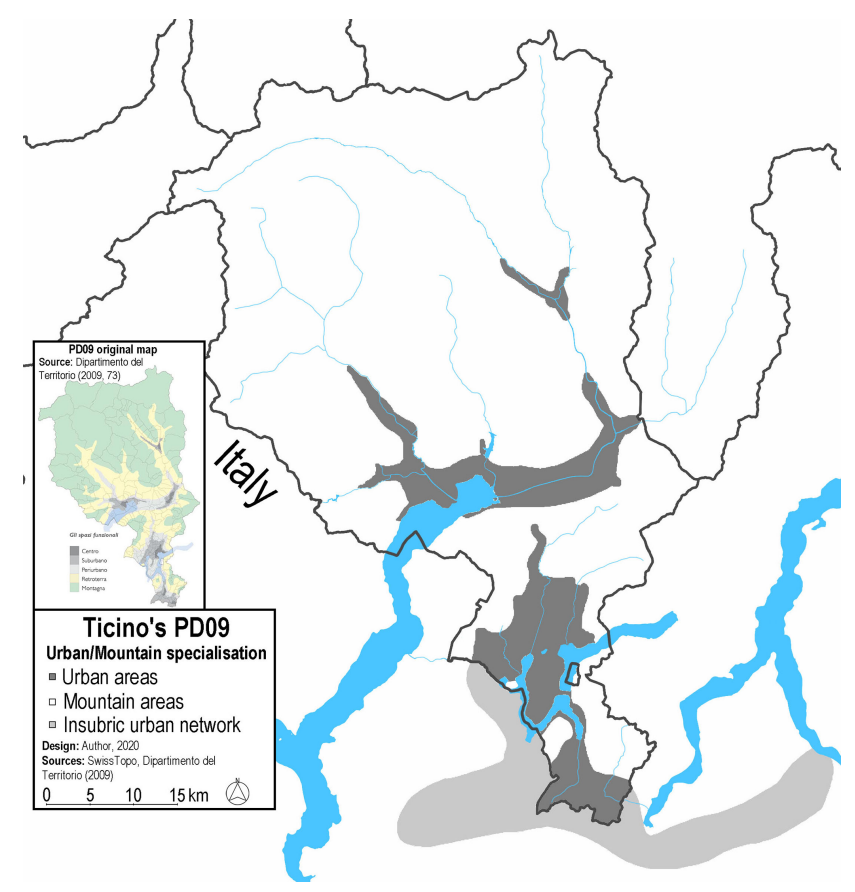

Figure 3. Ticino’s 2009 master plan objectives.

whereas the minimum size for a functional municipality was estimated at 1200 inhabitants (RCT, 1998a:86).

Faced with a predicted crisis in terms of global competitiveness (RCT, 2009:34; Rossi, 2008:29) and with the growing importance of Lugano (RCT, 2006:8), the canton decided to strengthen its urban system. Cantonal authorities seemed to be persuaded that they do not have sufficient resources to redress internal socio-territorial disparities and therefore opted for a solution that includes these as one of the central elements of the new approach (RCT, 2009:40-46). This involved abandoning the policy of developing peripheral areas and rather fostered new forms of rural-urban cooperation. What emerges is a paradigm of functional specialisation: urban regions must focus on improving their attractiveness, reinforcing their network with neighbouring Italian cities, while Alpine regions must develop in terms of tourism and agriculture (Fig. 3). PD09 should be "taking better account of the relationship between urban and mountain areas, in particular through policies aimed at tourism, recreation and heritage enhancement" (RCT, 2006:8). This is an important transformation for peripheral areas. The political discourse imbuing PD09 completely abandons references to internal solidarity towards peripheral regions (Table 1) and instead pushes for them to specialise in tourism in order to contribute to the overall competitiveness of the canton. Their objective will no longer be subsidised economic development but only the maintenance of basic services to avoid the decline of the resident population (RCT, 2006:12) - indeed, the demographic disparities between peripheral and urban areas have further increased: "this differentiated evolution has meant that today more than four out of five people live in urban areas (86.8\% in 2007), almost half of whom (45.8\%) live in the Lugano area" (RCT, 2009:36).

Thus, once it had recognised the undisputed centrality of Lugano - which must, however, continue to develop its own structure so as not to become a mere periphery of Milan (RCT, 2009:5) - the canton opted for a new policy towards peripheral municipalities (RCT, 2009:70). Among the instru- 
ments devised, that of aggregation had an important role to play since it sought to safeguard the economic autonomy of declining regions while encouraging their modernisation ( $\mathrm{Pi}$ lotti, 2013). This strategy also included support for two (unsuccessful) national park projects (Michel, 2019; Cometta, 2020; Michel and Bruggman, 2019; Michel and Backhaus, 2019; Cometta, 2021a), which were supposed to promote tourism throughout the entire canton. For the purpose of this paper, it is not necessary to elaborate more on the territorial policies of 2009, but rather the paper highlights this functional change of peripheral areas.

\section{Discussion}

\subsection{The evolution of territorial policies}

What we have seen in the case of Ticino is not unique but rather represents a classic case of neoliberal transformation of territorial policies (Allmendinger and Haughton, 2013; Haughton et al., 2013; Olesen, 2012; Ranci, 2017). Although it is neither simple nor immediate to establish a link between neoliberal ideology and spatial planning (Olesen, 2013), it is clear that the insistence on the need to increase urban competitiveness and the abandonment of internal solidarity for peripheral regions respond to a neoliberal logic - perhaps best expressed by the idea that planning should focus not on righting historical inequities but on realising new opportunities (Del Priore and Celio, 2006). This is a clear example of how trends in spatial planning not only affect the large metropolises but are in fact common, in their own ways, to semi-peripheral regions such as Ticino (Cometta, 2021b). "Over the last three decades of the twentieth century, progressive forms of regionalism aimed at reducing spatial inequalities almost disappeared. They were replaced by a neoliberal or, perhaps more accurately, neoconservative regionalism that was essentially entrepreneurial and dominated by intensified pressures to compete for a place in the global economy rather than dealing directly with issues of poverty and uneven development" (Soja, 2010:65). We can call the new form of spatial planning neoliberal because the guiding criterion for decisions comes from the economic world: the notion of competitiveness.

If we take a step back and analyse the question from a theoretical point of view, we realise that, in turn, this idea is linked to that of crisis, a structurally recurring theme in capitalism. In the Middle Ages, the term indicated the culminating moment in which the recovery from an illness was decided (Revault d'Allonnes, 2016:31): the crisis required the mobilisation of all available energies to deal with an extraordinary emergency situation. With the advent of an increasingly competition-oriented performance society (Han, 2017), however, the whole of society is always on the verge of a crisis - an insight that seems to be confirmed by the economic analysis of the crisis-prone structure of capitalism (Marx, 1981). In this sense, we can consider the present to be devel- oping in what amounts to a crisis paradigm. The competition of capitalism unfolds not only in the free market of goods and labour but also on a territorial level. Infrastructures, laws and cultures facilitate the competition among places to appropriate more resources on a global scale. As companies and institutions relocate, they constantly reshape the nodes of centrality. New regions emerge as dynamic hubs, while others decline, losing attractiveness and jobs. This phenomenon has been extensively researched by Harvey (2010:295), who described it as the spatial fix of capitalism, a way to consume the constantly emitted overproduction and thus avoid even more frequent systemic crises. It is in this framework, accepting these perspectives, that PD09 develops, distancing itself from the more political-moral perspective of PD90.

\subsection{Criteria of planning}

The aim of this paper is to discuss the perspectives underlying the two Ticino cantonal master plans and to understand their broader implications. In order to do this, it is necessary to look at the relationship between the centre and the periphery of the canton. Although several studies show that there is no clear-cut duality between the centre and the periphery (Bauer and Roux, 1976; Indovina, 1990; Vanier, 2000; Lefebvre, 2001, 1970) - but rather a complex series of gradients (Lévy, 1994) - for the purposes of this research, it is important to underline more sharply the differences between the centrality and the periphery in order to observe changes in the balance of power. Of course, this does not mean falling back on a simple binary view but merely focusing on the transformation of the balance of power within a given territory. It is in managing this relationship between the rich and dynamic urban centres and the peripheral Alpine valleys, which are undergoing depopulation and lacking in prospects, that these founding principles emerge most clearly.

As mentioned, PD90 attempted to limit the socioterritorial imbalance resulting from the canton's rapid urban transition. There are several reasons for this: since the Second World War, the few areas on the valley floor had been enjoying significant growth due to the huge influx of capital. This resulted in a further shift in the demographic distribution of the canton in favour of the lowlands (Cometta, 2021b) and the abandonment of traditional subsistence farming practices, as well as the doubling of the number of buildings in the canton in just under 3 decades (Caccia, 1984:54) and the emergence of a previously non-existent class of landowners (Rossi et al., 1979:60-61). The planning work, which began in the 1980 s but was already being discussed by specialists from the 1960s onwards, was influenced by a Keynesian perspective (Carloni, 1998; Ceschi and Ghiringhelli, 1998), which "typically involved the centralization of regulatory capacities, the creation of uniform systems of local government and efforts to equalize public investment and infrastructure across the territory" (Colomb and Tomaney, 2020:102). From this point of view, the state was to be the guarantor of socio- 
economic development for the population as a whole. The task of the state was therefore to improve living conditions by also correcting economic trends, i.e. by supporting regions in decline. This was also possible because urban areas enjoyed good economic health and bright growth prospects and were therefore not of great concern. This perspective, in short, "implicitly presupposed a linear continuation of both crisis-free urbanization and expanded capital accumulation" (Brenner, 1997:287). Here, the basic requirement was to ensure a certain homogeneity in the social fabric and to ensure that no one was left behind on the road to progress, urbanisation and modernisation of society, what has been called a policy of decentralised centralisation - which has characterised Swiss spatial planning for decades (Diener et al., 2006) following the Swiss federal mentality (Linder, 2010). This meant that the state would invest directly, against economic criteria, in the development of infrastructure in the valleys (RCT, 1990:II.15). In concrete terms, it can be seen that in PD90 the peripheral regions are given disproportionate attention in relation to their economic or demographic weight, which can be explained precisely by the state's desire to socio-economically rebalance its territory so as not to create two distinct populations. This is crucial for the stability of an institutional system and for facilitating the recognition of its legitimacy (Bobbio, 1989): two distinct populations with distinct ways of life, desires and problems would be difficult to manage by a single political body.

PD09, on the other hand, is on a completely different level with regard to the theoretical-political assumptions of planning. This is a very interesting aspect since it shows how in a few years the perspective of the cantonal ruling group has changed radically. On the one hand, PD09 diagnoses a very different situation from that of PD90. We are no longer in an era of light-hearted, automatic economic growth. The prospect of a loss of attractiveness for the canton's urban regions in the medium term, combined with the structural and historical weaknesses of the economic fabric as well as the difficulties that emerged from the rapid pace of uncontrolled urban development in the mid-twentieth century - traffic growth and congestion, difficulties in transport systems, a lack of high-quality public spaces, a lack of coherence in urban development (Carloni, 2011) - led planners to emphasise the seriousness of the situation. In carrying out this analysis, the cantonal authorities recognised that they were not in full control of the situation. They recognised the important influence of external factors and that the canton was at the mercy of events (RCT, 2009:39, 62). The favourable economic situation was coming to an end, and Ticino did not have the strength to maintain its socio-economic development. This implied a change in territorial policy. The new criterion to be adopted is competitiveness since this alone can guarantee access to the funds necessary to develop the canton (Brenner, 1997:274). It is interesting to note that in Ticino this change in political and planning orientation took place at the beginning of the new millennium, 2 decades later than in other European areas (e.g. Brenner, 1997; Ranci, 2017). We can hypothesise that its small size and peripherality, as well as its belonging to a fundamentally conservative country - which tries to use old models and update them rather than adopt completely new ones (Diener et al., 2006:I, 137) - have slowed down the adoption of the new planning paradigm (Padioleau and Demesterre, 1991; Genestier, 1993; Motte, 2005). Other explanations may relate to the scarcity of its industrial fabric - so the canton was perhaps less directly affected by the post-Fordist transition. Another important aspect is certainly related to banking secrecy, which has allowed it to enjoy an important availability of funds for many decades.

By following the new principles of competitiveness, the canton is thus abandoning its desire to balance the various regions and to finance the development of the peripheral valleys in an uneconomic and countercyclical way. A new policy of functional specialisation is required, in which each region must develop its own potential, thus adapting to market forces; relieving the canton of costs; and, ideally, making the whole territory more interconnected. This means the end of an era when indirect cantonal planning disproportionately favoured peripheral regions in order to redress the balance and maintain strong internal solidarity. Even more so, in this new context, it is the disadvantaged peripheral regions that, having to accept that they can only specialise in tourism and agriculture, must work in solidarity with the urban centres in order to maintain an overall level of cantonal competitiveness.

\subsection{What conception of justice is in play?}

There is one last point worthy of discussion: the conception of territorial justice of the two master plans. PD90 and PD09 are political documents with legal value. They must therefore necessarily refer to a certain legitimacy: they are not arbitrary choices but positions that have been discussed between the different stakeholders and conceived as the best possible compromise in that situation. Since they deal with the socioterritorial configuration of the canton, they must - at least indirectly - necessarily refer to the idea of a certain spatial justice. It is therefore interesting to try to reconstruct how, indirectly, these two documents conceive spatial justice.

In the theoretical perspective that accompanies and justifies PD90, the emphasis is on the importance of each municipality receiving similar treatment and of socio-economic differences between different municipalities - especially between peripheral and central ones - being reduced. This means, in essence, that the policy of PD90 is based on the municipalities as the main actors and that it therefore conceives of local communities as the cornerstone of Swiss society. Since the Swiss are so closely tied to their local collective identities (Diener et al., 2006) - to the point of developing a confederal political structure to maintain the autonomy of the lower levels (Linder, 2010) - these are considered indispens- 
able players. Territorial policy, with a view to equity, must therefore guarantee equal treatment of these collective bodies, which represent the political essence of the Swiss people. This shows that PD90 maintains a strong link with Swiss political traditions, with a traditional and ultimately collectivist understanding of society. The bond of belonging to a local reality is indeed strong and central, especially in sedentary communities, e.g. having an agriculture-based economy - as Ticino did until the first half of the twentieth century.

However, contemporary society is not rural, and its ways of life have also changed considerably. Although an ideal attachment to one's commune of origin can be maintained, people are now influenced by a polytopic lifestyle (Stock, 2006). People organise their lives in a modular way, connecting to distinct activities and places that do not necessarily have to maintain a bond of coherence or proximity (Benasayag and Del Rey, 2015). This means that each individual will have a personalised attachment to places where they are born: the collectivist assumptions that all Swiss people are necessarily bound to their commune of origins and that therefore the municipality is the fundamental political unit from which considerations of territorial justice are based are no longer valid. It is from this renewed perspective - closer to the neoliberal individualism hegemonic throughout the West - that PD09 is organised. In this case, it is the citizens and not the local communities who should be treated equally. This means that a policy of positive discrimination in favour of peripheral municipalities is unfair to other inhabitants of the canton. This is why PD09 insists on the need for peripheral municipalities to specialise in tourism and agriculture, thus contributing to the overall competitiveness of the canton. This transformation changes the canton's planning priorities by no longer giving disproportionate attention (compared to their economic and demographic weight) to peripheral areas.

Both of these visions are ultimately based on a concept of equity and spatial justice. On the one hand, PD90, by attempting to favour peripheral areas in order to rebalance the socio-economic situation of the canton, focuses less on the importance of improving the fabric of its urban centres. In other words, it is an approach that tends to be conservative, maintaining the central role of mountain villages despite the demographic and economic depletion of those regions. Among other things, this view encourages identity attachment to a biased reconstruction of the past (see Niklasson and Hølleland, 2018). On the other hand, PD09, by focusing only on the individual dimension, effectively stops considering the economic and socio-political balance between different municipalities and regions. This is a typical problem of the neoliberal perspective, which tries to apply economic solutions to problems that are political in nature (Hadjimichalis, 2011). In doing so, it excludes and subjugates to the interests of the centres the groups living in peripheral regions, creating de facto two classes of citizens or two distinct populations something that generates a number of problems and resis- tance to the plans of the cantonal authorities from the peripheries (see Cometta, 2021a).

\section{Conclusions}

This paper attempted to show the criteria and perspectives adopted by two master plans, thus shedding light on the historical evolution of the authorities' discourses. We have explored the example of Ticino and shown how institutions, deciding on the spatial planning to be carried out, materialise a determined vision of the world that changes according to the ruling group and the politically and culturally hegemonic perspective. The transformation of the discursive framework is derived in the adoption of distinct policies, e.g. regarding the choice of the relevant stakeholders. While PD90 considered municipalities as the fundamental political unit and thus as the referent in its action of reconstructing equity, PD09 made its choices focusing on population density, i.e. choosing individuals as the fundamental criterion. Both positions have advantages and disadvantages, as both foster some kind of exclusion. The type of analysis proposed by this paper, by highlighting these features, shows its novelty and usefulness: combining philosophy and social sciences by carrying out discursive analyses of spatial planning documents can contribute to contextualising - i.e. criticising - the choices and criteria used, making the public debate around these issues more informed. This, in turn, should encourage planning decisions that are more representative of the common interest, thus contributing in part to the realisation of the right to the city (Lefebvre, 1968; Attoh, 2011; Harvey, 2008; Marcuse, 2010).

This type of analysis cannot and should not, of course, supplant more traditional, empirical analyses of the types of policies used or their concrete effects - analyses that fit well within established disciplinary traditions. On the contrary, these two strands of research can be mutually enriching. Thus, it can be said that this approach opens numerous avenues: on the one hand, that of working as experts in the movement to promote more inclusive spatial planning (see Caldeira and Holston, 2015; Dennis, 2006; and for the limits of this approach see Kaza, 2006) and, on the other, that of deepening the interdisciplinary work of uniting philosophy and the social sciences, broadening horizons, and overcoming disciplinary boundaries.

In concrete terms, this study opens several interesting lines of research. New studies are needed to analyse the discursive evolution of other master plans in Switzerland and abroad. It would be interesting for these studies to be structurally integrated into future revisions of master plans. Concerning Ticino, it would be interesting to observe more closely, with a series of interviews, not only the ideological but also the methodological transition in the design of the two plans. Although such research exceeds the limits of this paper, its development could strengthen our argument. New studies on 
this cantonal reality and on the concrete effects of territorial and economic policies are also necessary to provide more precise data and to foster future discussions.

Data availability. The dossiers on Ticino's master plans can be found on the website of the Department of the Territory (https://www4.ti.ch/dt/dstm/sst/temi/piano-direttore/ piano-direttore/piano-direttore/, last access: 29 November 2021; Repubblica e Cantone Ticino, 2009) and in the library of the Academy of Architecture in Mendrisio.

Competing interests. The contact author has declared that there are no competing interests.

Disclaimer. Publisher's note: Copernicus Publications remains neutral with regard to jurisdictional claims in published maps and institutional affiliations.

Acknowledgements. I would like to thank the reviewers for their valuable advice and constructive criticism.

Financial support. This research has been supported by the Schweizerischer Nationalfonds zur Förderung der Wissenschaftlichen Forschung (grant no. POLAP1-172054/1).

Review statement. This paper was edited by Myriam HoussayHolzschuch and reviewed by three anonymous referees.

\section{References}

Allmendinger, P. and Haughton, G.: The Evolution and Trajectories of English Spatial Governance: 'Neoliberal' Episodes in Planning, Planning, Practice \& Research, 28, 6-26, 2013.

Ambal, J.: Projets urbains et imaginaires de la mobilité, les nouveaux récits de la fabrique métropolitaine: le cas du mégaprojet Bordeaux Euratlantique, Université de Bordeaux, Bordeaux, 2019.

Antonini, B.: Principi operativi e metodo di lavoro del Piano direttore del Canton Ticino, Rivista Tecnica, 5, 84-90, 1983.

Arboleda, M.: Financialization, totality and planetary urbanization in the Chilean Andes, Geoforum, 67, 4-13, 2015.

Attoh, K. A.: What kind of right is the right to the city?, Prog. Hum. Geog., 35, 669-685, 2011.

Bauer, G. and Roux, J. M.: La rurbanisation; ou, La ville éparpillée, Éditions du Seuil, Paris, 189 pp., 1976.

Benasayag, M. and Del Rey, A.: Clinique du mal-être: la "psy" face aux nouvelles souffrances psychiques, La Découverte, Paris, 2015.

Bobbio, N.: Democracy and dictatorship: the nature and limits of state power, Polity, Oxford, UK; Malden, Mass, 186 pp., 1989.
Brenner, N.: State territorial restructuring and the production of spatial scale, Polit. Geogr., 16, 273-306, https://doi.org/10.1016/S0962-6298(96)00003-0, 1997.

Brenner, N.: Debating planetary urbanization: For an engaged pluralism, Environ. Plann. D, 36, 570-590, 2018.

Caccia, F.: Costruzioni fuori dalle zone edificabili, Rivista Tecnica, 10, 54-56, 1984.

Caldeira, T. and Holston, J.: Participatory urban planning in Brazil, Urban Studies, 52, 2001-2017, https://doi.org/10.1177/0042098014524461, 2015.

Callon, M.: Sociologie de l'acteur réseau, in: Sociologie de la traduction: Textes fondateurs, edited by: Akeich, M., Callon, M., and Latour, B., Presses des Mines, Paris, 2006.

Carloni, T.: La grande trasformazione del territorio, in: Storia del Cantone Ticino, vol. II, edited by: Ceschi, R., Stato del Cantone Ticino, Bellinzona, 671-700, 1998.

Carloni, T.: Pathopolis, Casagrande, Bellinzona, 2011.

Ceschi, R.: Il territorio e gli abitanti, in: Storia del Cantone Ticino, vol. I, edited by: Ceschi, R., Stato del Cantone Ticino, Bellinzona, 15-32, 1998.

Ceschi, R. and Ghiringhelli, A.: Dall'intesa di sinistra al governo quadripartito (1947-1995), in: Storia del Cantone Ticino, vol. II, edited by: Ceschi, R., Stato del Cantone Ticino, Bellinzona, 551576, 1998.

CF: Politique des agglomérations de la confédération, Rapport du Conseil fédéral du 19 décembre 2001, Bern, 2001.

Colomb, C. and Tomaney, J.: Spatial planning, nationalism and territorial politics in Europe, Reg. Studies, 55, 101-114, https://doi.org/10.1080/00343404.2020.1744552, 2020.

Cometta, M.: Protected Areas and Territorial Tensions: The Ticinese Case of Adula Park, ecomont, 12, 4-10, https://doi.org/10.1553/eco.mont-12-2s4, 2020.

Cometta, M.: Culture wars and protected areas: narratives against national parks. An exploratory qualitative comparison of the movements opposing Adula Park and Locarnese Park, ecomont, 13, 5-11, https://doi.org/10.1553/eco.mont-13-2s5, $2021 \mathrm{a}$.

Cometta, M.: Tessin et urbanisation néolibérale: évolution des discours en matière d'aménagement, Géo-Regards, 13, 85-101, 2021b.

Del Priore, F. and Celio, M.: Il Piano direttore, strumento strategico per una politica cantonale dello sviluppo territoriale, Dati Statistiche e società, I, 6-7, 2006.

Dennis, S. F.: Prospects for Qualitative GIS at the Intersection of Youth Development and Participatory Urban Planning, Environ Plan A, 38, 2039-2054, https://doi.org/10.1068/a3861, 2006.

Diener, R., Herzog, J., Meili, M., de Meuron, P., and Schmid, C.: Switzerland. An Urban Portrait, Birkhäuser, Basel, 2006.

Foucault, M.: The order of things: an archaeology of the human sciences, Repr., Routledge, London, 422 pp., 2006.

Foucault, M.: La volonté de savoir, in: Euvres, vol. II, Gallimard, Paris, 617-738, 2015

Gaeta, L.: La democrazia dei confini, Carocci, Roma, 2011.

Genestier, P.: Que vaut la notion de projet urbain?, L'Architecture d'aujourd'hui, 288, 40-46, 1993.

Ghiringhelli, A.: La costruzione del Cantone (1803-1830), in: Storia del Cantone Ticino, vol. I, edited by: Ceschi, R., Stato del Cantone Ticino, Bellinzona, 33-62, 1998.

Gramsci, A.: Prison Notebooks, Lawrence \& Wishart, London, 1971. 
Hadjimichalis, C.: Uneven geographical development and sociospatial justice and solidarity: European regions after the 2009 financial crisis, Eur. Urban Reg. Stud., 18, 254-274, 2011.

Hajer, M. A.: Discourse Analysis, in: The Politics of Environmental Discourse: Ecological Modernization and the Policy Process, Oxford Scholarship Online, Oxford, 2003.

Han, B.-C.: Psychopolitics, Verso, London, 2017.

Harvey, D.: The Right to the City, 53, 23-40, 2008.

Harvey, D.: Justice, Nature and the Geography of Difference, Blackwell, Oxford, 2010.

Harvey, D.: The urban roots of financial crises: reclaiming the city for anti-capitalist struggle, 48, 1-35, 2011.

Haughton, G., Allmendinger, P., and Oosterlynck, S.: Spaces of neoliberal experimentation: soft spaces, postpolitics, and neoliberal governmentality, Environ. Plann. A, 45, 217-234, 2013.

Horkheimer, M. and Adorno, T. W.: Dialectic of Enlightenment, Stanford University Press, Stanford, 2002.

Indovina, F. (Ed.): La città diffusa, IUAV-DAEST, Venezia, 1990.

Kanai, J. M.: On the peripheries of planetary urbanization: globalizing Manaus and its expanding impact, Environ. Plann. D, 32, 1071-1087, 2014.

Kaza, N.: Tyranny of the Median and Costly Consent: A Reflection on the Justification for Participatory Urban Planning Processes, Planning Theory, 5, 255-270, https://doi.org/10.1177/1473095206068630, 2006.

Kohlbacher, F.: The Use of Qualitative Content Analysis in Case Study Research, Forum: Qualitative Social Research, 7, 2006.

Lefebvre, H.: Le droit à la ville, Anthropos, Paris, 1968.

Lefebvre, H.: La révolution urbaine, Gallimard, Paris, 1970.

Lefebvre, H.: The production of space, Blackwell, Oxford, OX, UK; Cambridge, Mass., USA, 454 pp., 1991.

Lefebvre, H.: Du Rural à l'Urbain, Anthropos, Paris, 2001.

Lepori, A.: Vicende e problemi del Piano Direttore nelle discussioni sull'urbanistica nel Ticino, Rivista Tecnica, 3, 51-55, 1981.

Lévy, J.: L'espace légitime: sur la dimension géographique de la fonction politique, Presses de la Fondation nationale des sciences politiques, Paris, 442 pp., 1994.

Limouzin, P.: Le Tessin: Les mutations économiques et sociales d'un canton périphérique, Annales De Géographie, 99, 173-179, 1990.

Linder, W.: Swiss democracy: possible solutions to conflict in multicultural societies, 3rd ed., Palgrave Macmillan, New York, 246 pp., 2010.

Maggiori, M., Morosi, B., and Büchler, M.: I principali strumenti pianificatori e l'evoluzione della legislazione in materia di pianificazione del territorio, available at: https://m4.ti.ch/fileadmin/DT/ temi/piani_regolatori/documenti/Pianificazione_Ti.pdf (last access: 29 November 2021), 2003.

Marcuse, P.: From critical urban theory to the right to the city, City. Analysis of urban trends, culture, theory, policy, action, 13, 185197, 2010.

Marx, K.: Capital: a critique of political economy, Penguin Books in association with New Left Review, London; New York, NY, 1 p., 1981.

Mazzoleni, O.: Quale mutamento?, in: Un cantone in mutamento, edited by: Mazzoleni, O., Pilotti, A., and Marcacci, M., Opera Nuova, Lugano, 2013.
Michel, A. H.: How conceptions of equity and justice shape national park negotiations: The case of Parc Adula, Switzerland, 11, 25$31,2019$.

Michel, A. H. and Backhaus, N.: Unravelling Reasons for the Non-Establishment of Protected Areas: Justification Regimes and Principles of Worth in a Swiss National Park Project, environ values, 28, 171-190, https://doi.org/10.3197/096327119X15515267418511, 2019.

Michel, A. H. and Bruggman, A.: Conflicting Discourses: Understanding the Rejection of a Swiss National Park Project Using Data Analysis Triangulation, Mt. Res. Dev., 39, R24-R36, 2019.

Morel Journel, C. and Pinson, G. (Eds.): Debating the neoliberal city, Routledge, Taylor \& Francis Group, London; New York, NY, 220 pp., 2017.

Motte, A.: La notion de planification stratégique spatialisée (Strategic Spatial Planning) en Europe (1995-2005), PUCA, Paris, 2005.

Mucchielli, A.: Contenu (analyse de), edited by: Mucchielli, A., Dictionnaire des méthodes qualitatives en sciences humaines et sociales, Armand Colin, Paris, 1996.

Niklasson, E. and Hølleland, H.: The Scandinavian far-right and the new politicisation of heritage, J. Social Archaeol., 18, 121-148, https://doi.org/10.1177/1469605318757340, 2018.

Olesen, K.: Soft spaces as vehicles for neoliberal transformations of strategic spatial planning?, Environ. Plann. C, 30, 910-923, 2012.

Olesen, K.: The neoliberalisation of strategic spatial planning, Plan. Theor., 13, 288-303, 2013.

OST: Lo sviluppo territoriale nel Cantone Ticino. Rapporto 2008, available at: https://m4.ti.ch/fileadmin/DT/temi/piano_direttore/ osservatorio_sviluppo_territoriale/documenti/OST_rapporto_ 08.pdf (last access: 29 November 2021), 2008.

OST: Il Ticino non urbano. Rapporto 2010, available at: https://www4.ti.ch/fileadmin/DT/temi/piano_direttore/ osservatorio_sviluppo_territoriale/rapporti/Rapporto_OST_ Ticino_non_urbano_2010.pdf (last access: 29 November 2021), 2010.

OST: Distribuzione e centralità dei servizi nel Cantone Ticino. Un confronto 2001-2012, available at: https: //www.arc.usi.ch/sites/www.arc.usi.ch/files/attachments/aam_ istituti_ost_rap_2016_distribuzione_centralita_servizi_ti.pdf (last access: 29 November 2021), 2016.

Ostrowetsky, S.: Des mots, des choses et des lieux, in: L'esprit de société, edited by: Decrosse, A., Mardaga, Liège, 1993.

Padioleau, J.-G. and Demesterre, R.: Les démarches stratégiques de planification des villes. Origines, exemples et questions, Les Annales de la Recherche Urbaine, 51, 29-40, 1991.

Pilotti, A.: Le aggregazioni urbane degli anni Duemila, in: Un cantone in mutamento, edited by: Mazzoleni, O., Pilotti, A., and Marcacci, M., Opera Nuova, Lugano, 2013.

Ranci, C.: Neoliberalism and the European city: reshaping the competitiveness/social cohesion nexus, in: Debating the neoliberal city, edited by: Morel Journel, C. and Pinson, G., Routledge, Taylor \& Francis Group, London; New York, NY, 136-152, 2017.

RCT: Progetto di Piano direttore cantonale, Ticino canton, Bellinzona, 1990.

RCT: 245 Comuni alla lente. Situazione e prospettive degli enti locali ticinesi, Ticino canton, Bellinzona, 1998a. 
RCT: Il Cantone ed i suoi comuni. L'esigenza di cambiare, Ticino canton, Bellinzona, 1998b.

RCT: Rapporto sugli indirizzi, Ticino canton, Bellinzona, 2003.

RCT: Rapporto sulla consultazione: Un progetto per il Ticino, Ticino canton, Bellinzona, 2006.

RCT: Gli obiettivi pianificatori cantonali, Ticino canton, Bellinzona, 2007.

RCT: Revisione del Piano direttore cantonale: Rapporto esplicativo 2009, Ticino canton, Bellinzona, 2009.

Repubblica e Cantone Ticino: Piano direttore (PD), available at: https://www4.ti.ch/dt/dstm/sst/temi/piano-direttore/ piano-direttore/piano-direttore/ (last access: 29 November 2021), 2009.

Revault d'Allonnes, M.: La crise sans fin, Éditions du Seuil, Paris, 2016.

Richardson, T. and Jensen, O. B.: Linking Discourse and Space: Towards a Cultural Sociology of Space in Analysing Spatial Policy Discourses, Urban Studies, 40, 7-22, 2003.

Rossi, A.: La regione funzionale urbana di Lugano, Rivista Tecnica, 11, 43-52, 1986.

Rossi, A.: Lo sviluppo della regione urbana del Luganese, Commissione regionale dei trasporti del luganese, Lugano, 2008.

Rossi, A., Consolascio, E., and Bosshard, M.: Costruzione del territorio e spazio urbano nel Cantone Ticino, Fondazione Ticino Nostro, Lugano, 1979.

Schmid, C. and Brenner, N.: Planetary urbanization, in: Urban constellations, edited by: Gandy, M., Jovis Verlag, Berlin, 10-13, 2011.
Shaw, K.: Planetary urbanisation: what does it matter for politics or practice?, Planning Theory \& Practice, 16, 588-593, 2015.

Soja, E.: Seeking Spatial Justice, University of Minnesota Press, London, 2010.

Stock, M.: L'hypothèse de l'habiter poly-topique: pratiquer les lieux géographiques dans les sociétés à individus mobiles, EspacesTemps.net, 16, 2006.

Todd, E.: L'invention de l'Europe, Éditions de Seuil, Paris, 2015.

Toppi, S.: La crescita economica (1945-1975): la ricerca di aperture e l'avvento del terziario, in: Storia del Cantone Ticino, vol. II, edited by: Ceschi, R., Stato del Cantone Ticino, Bellinzona, 615640, 1998a.

Toppi, S.: La crescita economica (1945-1975): la scommessa industriale, in: Storia del Cantone Ticino, vol. II, edited by: Ceschi, R., Stato del Cantone Ticino, Bellinzona, 593-614, 1998 b.

USTAT: Popolazione residente, dal 1850 al 2000, Ticino canton, Bellinzona, 2018.

Vanier, M.: Qu'est-ce que le tiers espace? Territorialités complexes et construction politique, Revue de Géographie Alpine, 88, 105$113,2000$.

Wodak, R. and Reisigl, M.: The discouse-historical approach, in: Methods of Critical Discourse Studies, edited by: Wodak, R. and Meyer, M., Sage, London, 2016. 